\title{
PHOSPHATE FERTILIZATION AND SHADING ON THE INITIAL GROWTH AND PHOTOCHEMICAL EFFICIENCY OF Campomanesia xanthocarpa O. Berg.
}

\author{
Juliana Milene Silverio ${ }^{1}$, Giselly Marques Espíndola ${ }^{1}$, Cleberton Correia Santos ${ }^{1 *}$, Silvana de Paula Quintão \\ Scalon $^{1}$, Maria do Carmo Vieira ${ }^{1}$ \\ ${ }^{1}$ Universidade Federal da Grande Dourados - UFGD, Faculty of Agricultural Science, Dourados, Mato Grosso do Sul, Brazil. \\ *cleber_frs@yahoo.com.br
}

Received for publication: 20/12/2018 - Accepted for publication: 04/06/2020

\begin{abstract}
Resumo
Adubação fosfatada e sombreamento no crescimento inicial e eficiência fotoquímica de Campomanesia xanthocarpa O. Berg. Campomanesia xanthocarpa O. Berg. (Gabirobeira, Myrtaceae) é uma espécie arbórea frutífera e nativa no Cerrado com diversos usos. Estudos de adubação mineral e condições luminosas com a espécie são incipientes. Assim, objetivou-se avaliar o crescimento inicial e aspectos fotoquímicos em $C$. xanthocarpa cultivada sob adubação fosfatada e níveis de sombreamento. $O$ experimento foi realizado em vasos plásticos e os fatores em estudo constituíram-se de cinco doses de fósforo: 0, 50, 100, 150 e $200 \mathrm{mg} \mathrm{kg} \mathrm{solo}{ }^{-1}$, e dois níveis de sombreamento: $0 \%$ (pleno sol) e $50 \%$. Os tratamentos foram arranjados em esquema fatorial 5 x 2, no delineamento de blocos casualizados, com quatro repetições. As maiores características de crescimento ocorreram aos 240 dias após o transplantio. O maior índice de clorofila foi nas folhas sombreadas. Os maiores valores das fluorescências variável e máxima da clorofila- $a$ foram com 10,8 e 11,6 mg P kg-1 em ambiente sombreado, e com 120,00 e $81,81 \mathrm{mg} \mathrm{P} \mathrm{kg}^{-1}$ sob pleno sol. A maior eficiência fotoquímica no fotossistema II $\left(\mathrm{F}_{\mathrm{v}} / \mathrm{F}_{\mathrm{m}}\right)$ foi sob pleno sol com $33,33 \mathrm{mg} \mathrm{P} \mathrm{kg}^{-1}$. A análise de componentes principais explicou $78,82 \%$ da variabilidade remanescente. As plantas de C. xanthocarpa sombreadas apresentaram maiores rendimentos fotoquímicos com adição de baixas doses de fósforo. A adubação fosfatada contribuiu na mitigação de danos fotoquímicos nas plantas jovens de C. xanthocarpa sob cultivo a pleno sol.

Palavras-chave: Cerrado, luz, gabirobeira, fotossistema II, análise multivariada.
\end{abstract}

\begin{abstract}
Campomanesia xanthocarpa O. Berg. ("Gabirobeira", Myrtaceae) is a versatile fruit tree species native in Cerrado. Studies of mineral fertilization and luminous conditions with the species are incipient. Thus, the aim was to evaluate the initial growth and photochemical aspects in C. xanthocarpa cultivated under phosphate fertilization and shading levels. The experiment was carried out in plastic pots and the factors under study consisted of five doses of phosphorus: $0,50,100,150$ and $200 \mathrm{mg} \mathrm{kg} \mathrm{soil}^{-1}$, and two shadings levels: $0 \%$ (full sun) and 50\%. The treatments were arranged in a $5 \times 2$ factorial scheme, in a randomized block design, with four replications. The greatest growth characteristics occurred at 240 days after transplantation. The highest chlorophyll index was seen in shaded leaves. The highest values of variable and maximum chlorophyll- $a$ fluorescence were with 10.8 and $11.6 \mathrm{mg} \mathrm{P} \mathrm{kg}^{-1}$ in shaded environments, and with 120.0 and $81.81 \mathrm{mg} \mathrm{P} \mathrm{kg}^{-1}$, under full sun. The highest photochemical efficiency in photosystem II $\left(\mathrm{F}_{\mathrm{v}} / \mathrm{F}_{\mathrm{m}}\right)$ was under full sun with 33.33 $\mathrm{mg} \mathrm{P} \mathrm{kg}{ }^{-1}$. The analysis of main components explained $78.82 \%$ of the remaining variability. The shaded $C$. xanthocarpa plants showed higher photochemical yields with the addition of low phosphorus doses. Phosphate fertilization contributed to the mitigation of photochemical damage in young plants of $C$. xanthocarpa cultivated under full sun.

Keywords: Cerrado biome, light, "gabiroba tree", photosystem II, multivariate analysis.
\end{abstract}

\section{INTRODUCTION}

The Brazilian Cerrado occupies an extension of approximately 2 million $\mathrm{km}^{2}$, representing $23 \%$ of Brazilian national territory, with vast habitats and high floristic diversity (CÂNDIDO et al., 2016). Among the native plants, Campomanesia xanthocarpa (Mart.) O. Berg, popularly known as "gabiroba tree" belongs to the family Myrtaceae, being a fruitful tree species, occurring mainly in moist and well-drained soils of the subareas of pinhais of capões and gallery forests in the phytogeographic domains of the Cerrado and Atlantic Forest (SOBRAL et al., 2015).

C. xanthocarpa plants have good potential owing to their agromedicinal properties, because their fruits are juicy and sweet, and can be consumed in natura or used in the production of jellies, sweets, juices, liqueurs and ice cream (LORENZI, 2008). As for medicinal properties, studies proved its efficacy in reducing blood cholesterol levels (KLAFKE et al., 2010), and the plant powder can be encapsulated and used (CIECILI et al., 2014), besides

FLORESTA, Curitiba, PR, v. 50, n. 4, p. 1741 - 1750, out/dez 2020.

Silverio, J. M. et.al.

ISSN eletrônico 1982-4688 
being a source of antioxidant compounds (ZUNINGA et al., 2018). The plants can also be used in the reconstitution of degraded areas and riparian forests (DALANHOL et al., 2017). Therefore, studies on the production of seedlings of fruit and native species are essential for the conservation of genetic diversity and sustainable development.

Generally, tree species present intrinsic characteristics regarding the light gradient considering their positioning in the forest, and studies that characterize the leaf responses to these conditions in the initial phase are essential. In this sense, it should be observed the level of luminosity to which they are exposed, since these variations can cause changes in morphophysiological characteristics, due to the use of light in the activities of photosystem II - PS II (CUNHA et al., 2016; TAIZ et al., 2017). Thus, information on the luminous requirements and acclimatization mechanisms of the species in the initial growth phase of the seedlings contribute to the establishment of forestry practices.

An important agronomic and forestry practice in the context of the production of seedlings of fruit tree species in tropical soils is phosphate fertilization. This is because in the Cerrado region, the soils are highly weathered, presenting high levels of iron and aluminum oxides (CAMARGO et al., 2010), and these oxides may fix phosphorus in the soil, hindering plant growth. The importance of phosphorus for plants is owing to its participation in various phases of the plant, such as the content of nutritive seed reserves, degree of root system development and growth rate (SANTOS et al., 2008), and also the photochemical and biochemical aspects of photosynthesis, as it participates in metabolic processes by forming adenosine triphosphate (ATP) and acting on energy maintenance (DOMINGUES et al., 2010; TAIZ et al., 2017).

We hypothesized in this study that phosphate fertilization contributes to the mitigation of damage on the PS II and promotes growth of C. xanthocarpa under luminous stress. Thus, the aim was to evaluate the initial growth and photochemical aspects in young plants of C. xanthocarpa grown under different levels of phosphorus and shading.

\section{MATERIAL AND METHODS}

The experiment was conducted from November 2017 to August 2018, in plastic pots, in the Faculty of

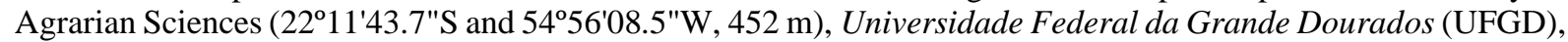
Dourados - Mato Grosso do Sul (MS), Brazil. Mature fruits of C. xanthocarpa were collected from natural populations (Access Register No. A9CDAAE - CGEN-MMA, of 10/15/2018), in the Itamarati Settlement, Ponta Porã (MS) (Figure 1A-B), in which the species was identified and the exsiccate was deposited in the Herbarium, UFGD (DDMS), under number 4644. For seedling propagation, sowing was done in 72-cell expanded polystyrene trays filled with commercial substrate $\left(\right.$ Tropstrato $^{\circledR}$ ) (Figure 1C).

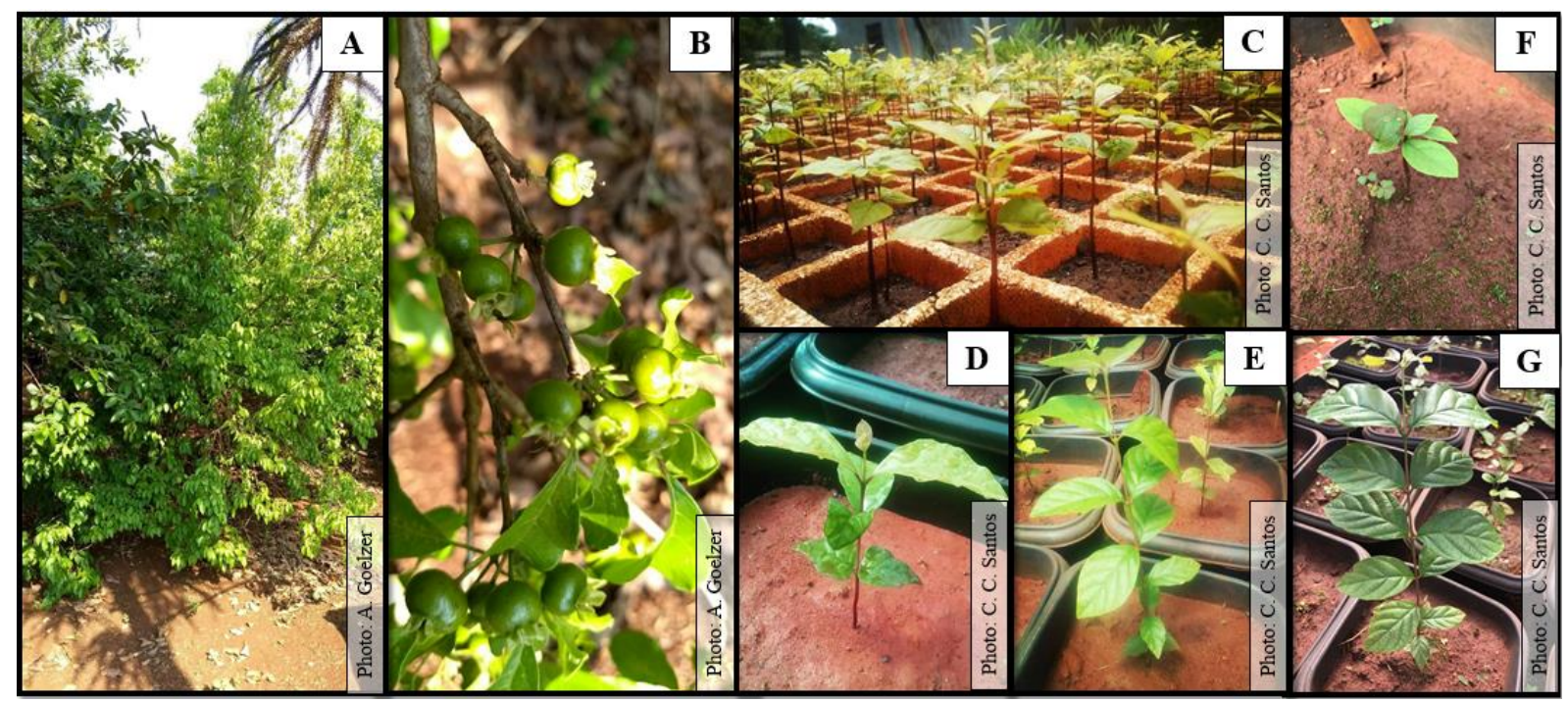

Figure 1. Plant (A), fruits (B), production of seedling (C), transplanting (D), growth (E, G) and leaf emission resprouting (F) of C. xanthocarpa $\mathrm{O}$. Berg.

Figura 1. Planta (A), frutos (B), produção de mudas (C), transplantio (D), crescimento (E, G) e emissão de folhas - rebrota (F) de C. xanthocarpa O. Berg.

FLORESTA, Curitiba, PR, v. 50, n. 4, p. 1741 - 1750, out/dez 2020.

Silverio, J. M. et.al.

ISSN eletrônico 1982-4688 
The factors studied consisted of five phosphorus levels, using simple superphosphate as source (18\% $\mathrm{P}_{2} \mathrm{O}_{5}$ ): 0, 50, 100, 150 and $200 \mathrm{mg} \mathrm{kg} \mathrm{soil}{ }^{-1}$, and two shading levels: $0 \%$ (full sun) and 50\%. The treatments were arranged in a $5 \times 2$ factorial scheme, in a randomized block design, with four replications. Shading was artificially set using black screens with retention of $50 \%$ of the solar radiation. At 60 days after sowing, that is, when the seedlings presented an average height of $6.0 \mathrm{~cm}$, the plants were transplanted to plastic vessels (Figure 1D-G) filled with $4.2 \mathrm{dm} 3$ of Dystroferric Red Latosol, with clayey texture, with the following chemical attributes: $\mathrm{pH}$ $\mathrm{CaCl}_{2}=4.76 ; \mathrm{P}=0.51 \mathrm{mg} \mathrm{dm}{ }^{-3} ; \mathrm{Ca}=1.04 \mathrm{cmol}_{\mathrm{c}} \mathrm{dm}^{-3} ; \mathrm{K}=0.06 \mathrm{cmol}_{\mathrm{c}} \mathrm{dm}^{-3} ; \mathrm{Mg}=0.12 \mathrm{cmol}_{\mathrm{c}} \mathrm{dm}^{-3} ; \mathrm{Al}=1.20 \mathrm{cmol}_{\mathrm{c}}$ $\mathrm{dm}^{-3} ; \mathrm{H}+\mathrm{Al}=7.71 \mathrm{cmol}_{\mathrm{c}} \mathrm{dm}^{-3} ;$ sum of bases $=1.22 \mathrm{cmol}_{\mathrm{c}} \mathrm{dm}^{-3}$; cationic exchange capacity $=8.93 \mathrm{cmol}_{\mathrm{c}} \mathrm{dm}^{-3} \mathrm{and}$ bases per saturation $(\mathrm{V} \%)=13.68$. Phosphorus was incorporated into the soil at the dose corresponding to each treatment, using concrete mixer for adequate homogenization. During the experimental period, irrigations were performed daily and spontaneous plant uproot was executed, when necessary.

Every 90 days, starting at 60 to 240 days after the transplant (DAT) of the seedlings to the pots, the height of plants was evaluated, using a ruler graduated in millimeters, having as standard the distance from the collar to the inflection of the highest leaf, stem diameter with digital caliper $( \pm 1.0 \mathrm{~cm}$ above the substrate level $)$ and counting the number of fully expanded leaves.

At 240 DAT, the chlorophyll index was determined using portable chlorophyll meter SPAD (Soil Plant Analyzer Development) (Konica Minolta SPAD 502), from 8:00 to 10:30 am. Soon after, the leaves were submitted to a dark condition, with leaf clips for 30 minutes, and evaluated for the initial $\left(\mathrm{F}_{0}\right)$, variable $\left(\mathrm{F}_{\mathrm{v}}\right)$ and maximum $\left(\mathrm{F}_{\mathrm{m}}\right)$ fluorescence of chlorophyll- $a$, and photochemical efficiency of photosystem II $\left(\mathrm{F}_{\mathrm{v}} / \mathrm{F}_{\mathrm{m}}\right)$, using portable fluorometer OS p 30 (OPTI-SCIENCES Chlorophyll Fluorometer, Hudson, USA). From these data, the efficiency of absorbed energy conversion $\left(\mathrm{F}_{\mathrm{v}} / \mathrm{F}_{0}\right)$ and maximum non-photochemical yield $\left(\mathrm{F}_{0} / \mathrm{F}_{\mathrm{v}}\right)$ was calculated.

The data was submitted to variance analysis (ANOVA), and when significant, according the F test ( $p<$ $0.05)$, the means were compared by Student t-test for shading, and regression analysis for phosphorus $(p \leq 0.05)$, using the SISVAR software. The growth characteristics were analyzed in plots subdivided in time, and when significant (F test), the means were compared by the Tukey test $(p \leq 0.05)$.

From the means of the data taken at the end of the cultivation cycle (240 DAT) multivariate analysis was performed from the matrix of variance and covariance through Principal Component Analysis (PCA), considering vectors with absolute value $>0.30$ (COELHO et al., 2003). Subsequently, all data were submitted to multivariate clustering analysis using the farthest neighbor method to describe the similarity between treatments, grouping data by classic method through Euclidean distances, and the analyses were performed with PAST software.

\section{RESULTS}

The height of C. xanthocarpa plants was influenced only by the evaluation times, being noticed that the highest height value $(19.72 \mathrm{~cm}$ ) occurred at 240 DAT, not differing statistically from the 150 DAT (Figure 2A). The stem diameter, number of leaves and height/diameter ratio (RHD) were influenced by the interaction between shading levels and days after transplantation (Table 1). Phosphate fertilization did not influence the height nor the number of leaves of the seedlings $(p>0.05)$. The stem diameter was also influenced by the interaction between phosphorus doses and shadings, and the largest diameter occurred in plants grown under full sun with increasing addition of $\mathrm{P}$, while in a shaded environments the data did not fit the mathematical models tested (Figure 2B).
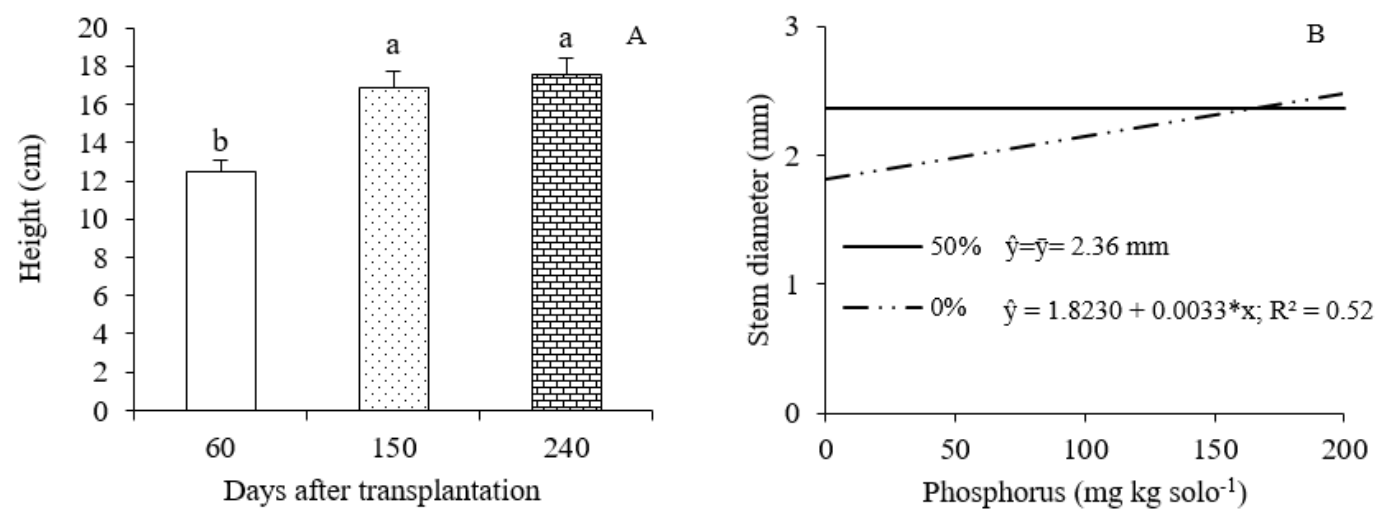

Figure 2. Height of plants of in function of days after transplantation (A) and stem diameter (B) of young plants of C. xanthocarpa O. Berg cultivated with phosphorus under shading levels. (A) Letters equal do not differ between them by Tukey's test $(p>0.05)$. (B) * $(p>0.05)$.

FLORESTA, Curitiba, PR, v. 50, n. 4, p. 1741 - 1750, out/dez 2020.

Silverio, J. M. et.al.

ISSN eletrônico 1982-4688 
Figura 2. Altura de plantas em função dos dias após o transplantio (A) e diâmetro do coleto (B) de plantas jovens de $C$. xanthocarpa $\mathrm{O}$. Berg cultivadas com fósforo sob níveis de sombreamento. Letras iguais não diferem entre si pelo teste de Tukey $(p>0,05)$.

Regarding the interaction between shadings and days after transplanting, the plants that presented the larger collar diameters and number of leaves were those produced under shaded, at 240 DAT (Table 1). The highest height/diameter ratio (RHD) was observed in shaded plants at 150 DAT, and this indicator was reduced at 240 DAT, in the same luminous environment.

Table 1. Stem diameter, number of leaves and height/diameter ratio (RHD) of $C$. xanthocarpa cultivated under shading levels in function of days after transplanting (DAT).

Tabela 1. Diâmetro do coleto, número de folhas e relação altura/diâmetro (RAD) de C. xanthocarpa cultivada sob níveis de sombreamentos em função dos dias após o transplantio (DAT).

\begin{tabular}{ccccccc}
\hline & \multicolumn{3}{c}{ Stem diameter $(\mathrm{mm})$} & \multicolumn{2}{c}{ Number of leaves } & \multicolumn{2}{c}{ RHD } \\
\hline & \multicolumn{9}{c}{ Shading levels } \\
\cline { 2 - 7 } DAT & $0 \%$ & $50 \%$ & $0 \%$ & $50 \%$ & $0 \%$ & $50 \%$ \\
\hline 60 & $1.95 \mathrm{aA}$ & $1.69 \mathrm{bB}$ & $9.1 \mathrm{aA}$ & $10.6 \mathrm{bA}$ & $6.16 \mathrm{bB}$ & $7.70 \mathrm{bA}$ \\
150 & $2.44 \mathrm{aA}$ & $1.87 \mathrm{bB}$ & $14.9 \mathrm{aA}$ & $15.4 \mathrm{bA}$ & $6.47 \mathrm{abB}$ & $9.99 \mathrm{aA}$ \\
240 & $2.05 \mathrm{aB}$ & $3.53 \mathrm{aA}$ & $10.0 \mathrm{aB}$ & $22.7 \mathrm{aA}$ & $7.78 \mathrm{aA}$ & $5.51 \mathrm{cB}$ \\
\hline C.V. (\%) & \multicolumn{2}{c}{24.12} & \multicolumn{2}{c}{44.97} & \multicolumn{2}{c}{25.25} \\
\hline
\end{tabular}

Lowercase letters in the column, for days after transplanting, and uppercase letters in the lines, for environments, do not differ from each other, by the Tukey test, and Student's $t$ test, respectively $(p>0.05)$.

The chlorophyll index and all chlorophyll- $a$ fluorescence indicators and photochemical of the activities on the PS II were influenced by the interaction of phosphorus and shading levels. Regarding the chlorophyll index, in the two light environments the data did not fit the mathematical models tested, with an average of 11.33 and 25.28 SPAD in leaves under sun and shades, respectively (Figure 3).

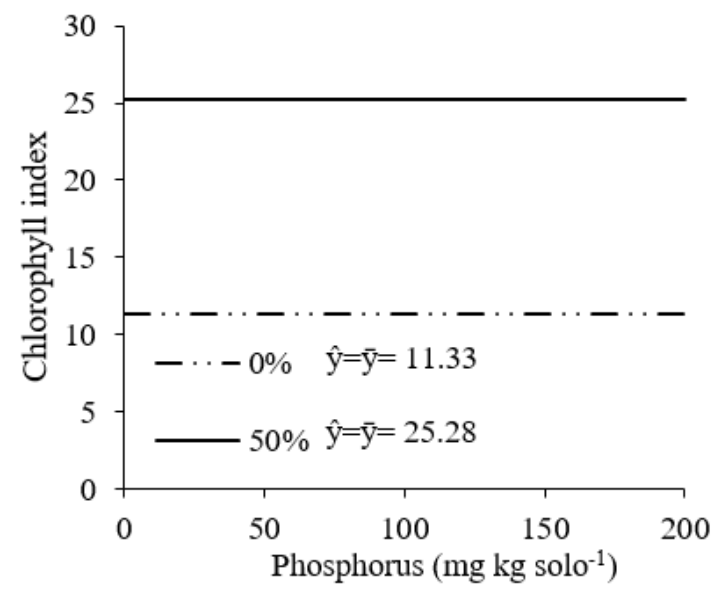

Figure 3. Chlorophyll index in leaves of C. xanthocarpa cultivated with phosphorus under shading levels, at 240 DAT.

Figura 3. Índice de clorofila em folhas de C. xanthocarpa cultivadas com fósforo sob níveis de sombreamento, aos 240 DAT.

The initial fluorescence data $-\mathrm{F}_{0}$ of the leaves of the shaded plants did not fit the mathematical models tested, while under full sun, the highest $\mathrm{F}_{0}$ was 0.134 electrons quantum ${ }^{-1}$ with the addition of $100 \mathrm{mg}$ of $\mathrm{P} \mathrm{kg} \mathrm{soil}^{-}$ ${ }^{1}$ (Figure 4A). Regarding the maximum fluorescence $\left(F_{m}\right)$, under full sun, the highest value was 0.415 photons quantum ${ }^{-1}$ with $120 \mathrm{mg}$ of $\mathrm{P} \mathrm{kg} \mathrm{soil}^{-1}$, and under shade it was 0.422 electrons quantum ${ }^{-1}$ with $11.6 \mathrm{mg}$ of $\mathrm{P} \mathrm{kg} \mathrm{soil}^{-}$ ${ }^{1}$ (Figure 4B). The highest variable fluorescence $\left(\mathrm{F}_{\mathrm{v}}\right)$ were 0.249 electrons quantum ${ }^{-1}$ with the addition of 81.81 mg $\mathrm{P} \mathrm{kg} \mathrm{soil}{ }^{-1}$, under full sun, and 0.298 electrons quantum ${ }^{-1}$ with the addition of $10.8 \mathrm{mg} \mathrm{P}$ soil $^{-1}$ in a shaded environment (Figure 4C).

Regarding the photochemical quantum efficiency of photosystem II $\left(\mathrm{F}_{\mathrm{v}} / \mathrm{F}_{\mathrm{m}}\right)$, the data in shaded environment did not fit the mathematical models tested, while under full sun the highest value (0.671 electrons quantum ${ }^{-1}$ ) occurred in the plants 0.671 with the addition of $33.33 \mathrm{mg} \mathrm{kg}^{-1}$ of $\mathrm{P}$ (Figure 4D). The absorbed energy

FLORESTA, Curitiba, PR, v. 50, n. 4, p. 1741 - 1750, out/dez 2020.

Silverio, J. M. et.al.

ISSN eletrônico 1982-4688 
conversion data $\left(\mathrm{F}_{\mathrm{v}} / \mathrm{F}_{0}\right)$ did not adjust in a shaded environment, with maximum efficiency under full sun with the addition of $113.0 \mathrm{mg} \mathrm{kg}^{-1}$ of $\mathrm{P}$ (Figure $\left.4 \mathrm{E}\right)$. The lowest and highest maximum non-photochemical yield $\left(\mathrm{F}_{0} / \mathrm{F}_{\mathrm{v}}\right)$ occurred under full sun with 110.7 and $10.4 \mathrm{mg} \mathrm{P} \mathrm{kg} \mathrm{soil}^{-1}$, respectively (Figure 4F).
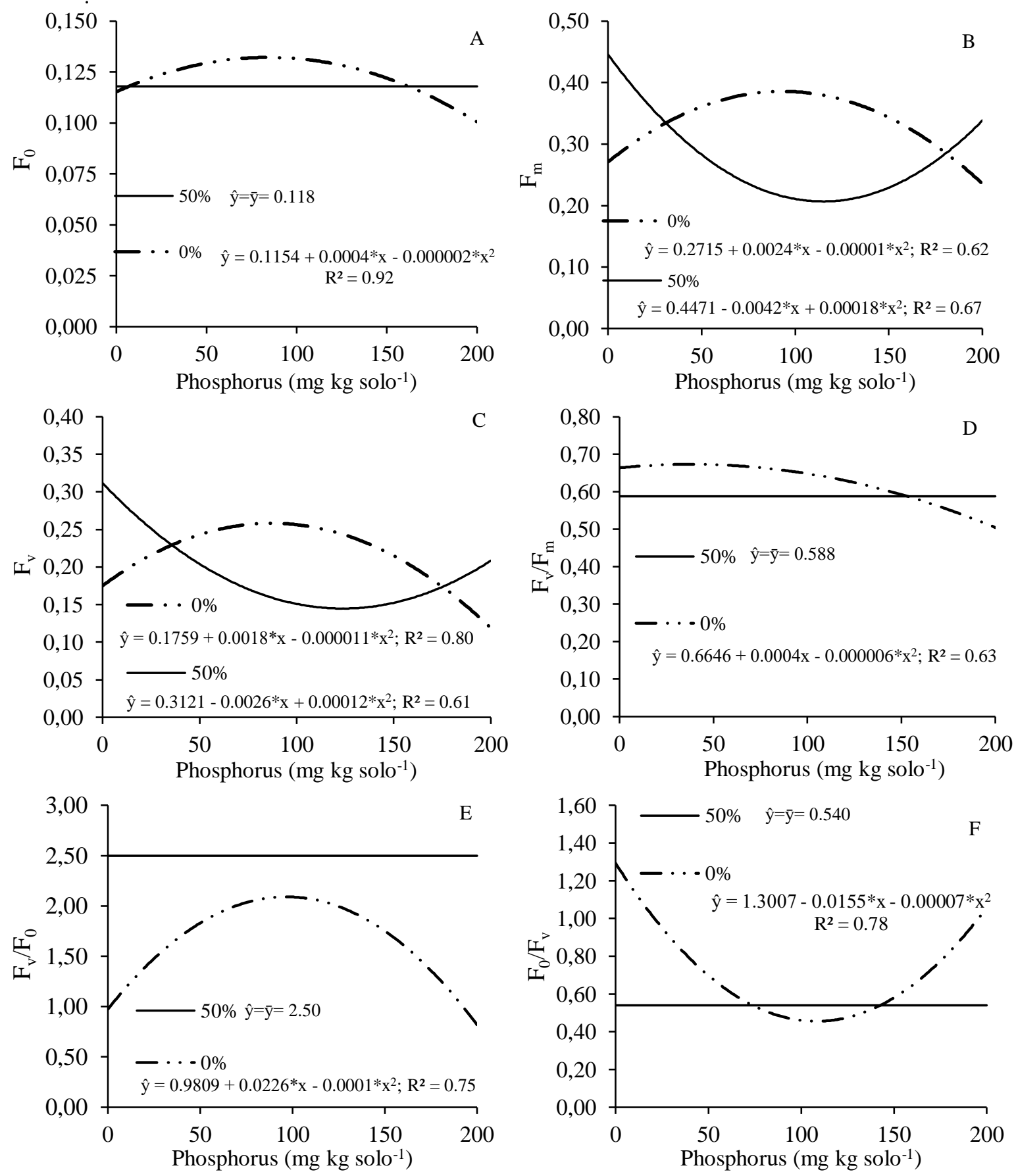

Figure 4. Initial $-\mathrm{F}_{0}(\mathrm{~A})$, variable $-\mathrm{F}_{\mathrm{v}}(\mathrm{B})$ and maximum $-\mathrm{F}_{\mathrm{m}}(\mathrm{C})$ fluorescence of chlorophyll- $a$, photochemical efficiency of photosystem II - $F_{v} / F_{m}(D)$, energy conversion absorbed $-F_{v} / F_{0}(E)$ and maximum non photochemical yield $-\mathrm{F}_{0} / \mathrm{F}_{\mathrm{v}}(\mathrm{F})$ of the leaves of $C$. xanthocarpa cultivated with phosphorus under shading levels. $*(p<0.05)$

Figura 4. Fluorescências inicial - $\mathrm{F}_{0}(\mathrm{~A})$, variável $-\mathrm{F}_{\mathrm{v}}(\mathrm{B})$ e máxima $-\mathrm{F}_{\mathrm{m}}(\mathrm{C})$ da clorofila-a, eficiência fotoquímica do fotossistema II $-F_{v} / F_{m}$ (D), conversão de energia absorvida $-F_{v} / F_{0}$ (E) e rendimento máximo não fotoquímico $-\mathrm{F}_{0} / \mathrm{F}_{\mathrm{v}}(\mathrm{F})$ de nas folhas de $C$. xanthocarpa cultivadas com fósforo sob níveis de sombreamento. $*(p<0,05)$.

FLORESTA, Curitiba, PR, v. 50, n. 4, p. 1741 - 1750, out/dez 2020.

Silverio, J. M. et.al.

ISSN eletrônico 1982-4688 
Principal component analysis explained $78.82 \%$ of the variability, in which PC 1 and PC 2 contributed with $45.75 \%$ and $33.07 \%$ to the remaining variance of the data, respectively (Figure 5). In PC 1, the characteristics that presented scores in decreasing order were $\mathrm{F}_{0}, \mathrm{RHD}, \mathrm{F}_{\mathrm{v}} / \mathrm{F}_{\mathrm{m}}$ and $\mathrm{SD}$, allocated in the environment of higher luminous availability in association with phosphate fertilization (Table 2). In PC 2, the characteristics that present scores in decreasing order $F_{0} / F_{v}, F_{v}, F_{v} / F_{0}, F_{m}$ and SPAD index, respectively, grouped in the environment of higher luminous availability (full sun) in association to phosphate fertilization.

Table 2. Autovectors and their respective photochemical and morphometric characteristics scores in $C$. xanthocarpa cultivated with phosphorus under shading levels, at 240 DAT.

Tabela 2. Autovetores e seus respectivos escores das características fotoquímicas e morfométricas em $C$. xanthocarpa cultivadas com fósforo sob níveis de sombreamento, aos 240 DAT.

\begin{tabular}{cccccccc}
\hline & PC 1 & PC 2 & PC 3 & PC 4 & PC 5 & PC 6 & PC 7 \\
\hline $\mathrm{F}_{0}$ & 0.3981 & 0.1450 & 0.4804 & 0.1717 & -0.1877 & -0.0114 & 0.7203 \\
$\mathrm{~F}_{\mathrm{m}}$ & 0.3459 & 0.3892 & -0.0226 & 0.3168 & -0.0434 & -0.3334 & -0.3683 \\
$\mathrm{~F}_{\mathrm{v}}$ & 0.2670 & 0.4720 & -0.1241 & 0.0761 & 0.2497 & -0.1889 & -0.1311 \\
$\mathrm{~F}_{\mathrm{v}} / \mathrm{F}_{\mathrm{m}}$ & 0.3727 & 0.2447 & 0.2664 & -0.5666 & 0.3289 & 0.4072 & -0.1762 \\
$\mathrm{~F}_{\mathrm{v}} / \mathrm{F}_{0}$ & -0.2783 & 0.4037 & -0.3686 & -0.3032 & 0.0744 & 0.2128 & 0.3524 \\
$\mathrm{~F}_{0} / \mathrm{F}_{\mathrm{v}}$ & 0.1502 & -0.5041 & 0.1680 & -0.0996 & 0.6178 & -0.2751 & 0.0356 \\
$\mathrm{SPAD}$ & -0.3884 & 0.2594 & 0.0712 & 0.4144 & 0.6212 & 0.0011 & 0.2198 \\
$\mathrm{SD}$ & -0.3481 & 0.1114 & 0.6209 & 0.2100 & -0.0743 & 0.3640 & -0.3514 \\
$\mathrm{RHD}$ & 0.3738 & -0.2194 & -0.3574 & 0.4751 & 0.1171 & 0.6586 & -0.0078 \\
\hline
\end{tabular}

$\mathrm{F}_{0}=$ Initial fluorescence; $\mathrm{F}_{\mathrm{m}}=$ maximum fuorescence; $\mathrm{F}_{\mathrm{v}}=$ variable fluorescence; $\mathrm{F}_{\mathrm{v}} / \mathrm{F}_{\mathrm{m}}=$ photochemical quantum efficiency of photosystem II; $\mathrm{F}_{\mathrm{v}} / \mathrm{F}_{0}=$ absorbed energy conversion; $\mathrm{F}_{0} / \mathrm{F}_{\mathrm{v}}=$ maximum non-photochemical yield; $\mathrm{SPAD}=$ chlorohyll index; $\mathrm{SD}=$ stem diameter; $\mathrm{RHD}=$ height/diameter ratio.

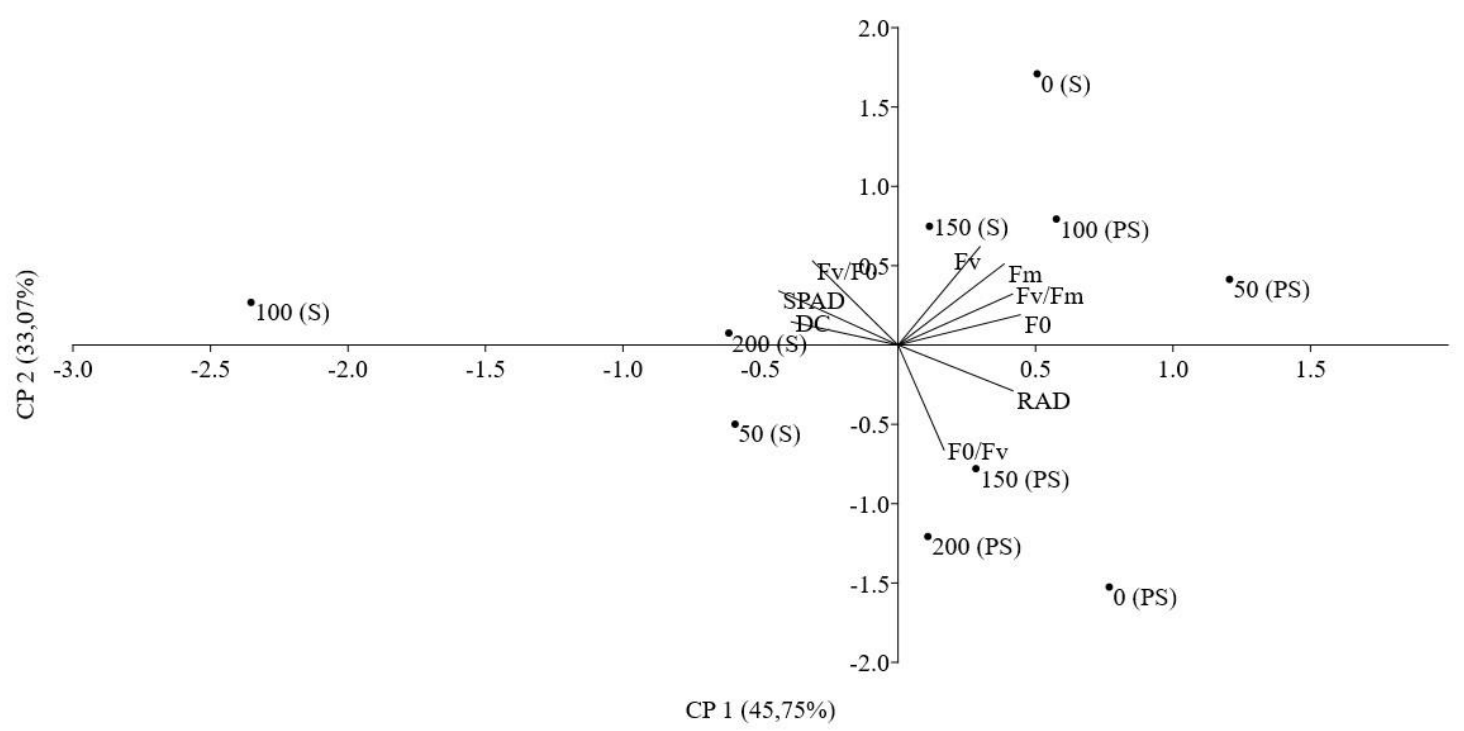

Figure 5. Principal components analysis (PCA) of characteristics evaluated in C. xanthocarpa cultivated with phosphorus $\left(0,50,100,150\right.$ and $200 \mathrm{mg} \mathrm{kg}^{-1}$ de soil $)$ under shading levels $(\mathrm{S}=$ shading and $\mathrm{PS}=$ full sun).

Figura 5. Análise de componentes principais (APC) das características avaliadas em C. xanthocarpa cultivadas com fósforo $\left(0,50,100,150\right.$ e $\left.200 \mathrm{mg} \mathrm{kg} \mathrm{solo}^{-1}\right)$ sob níveis de sombreamento $(\mathrm{S}=$ sombreado; $\mathrm{PS}=$ pleno sol), aos 240 DAT.

In the cluster analysis we observed the formation of three groups (G1, G2 and G3), and G1 consisted only of the shaded condition and $100 \mathrm{mg} \mathrm{P} \mathrm{kg}^{-1}-100$ (S) (Figure 6). In G2, four subgroups composed of the shaded environment were found except for the full sun treatment and a dose of $100 \mathrm{mg} \mathrm{P} \mathrm{kg}^{-1}$ (100 PS), and in G3 three

FLORESTA, Curitiba, PR, v. 50, n. 4, p. 1741 - 1750, out/dez 2020.

Silverio, J. M. et.al.

ISSN eletrônico 1982-4688 
subgroups were formed as to the full sun. Therefore, there was heterogeneity of the luminous environments, in which the smallest Euclidean distances occurred between the condition of full sun and doses of 150 and 200100 mg P kg-1 (P - 150 and 200, respectively), followed by treatment without adding $\mathrm{P}$ under shaded environment $(0$ $\mathrm{S})$ and $100 \mathrm{o} 0(\mathrm{~S})$ and $100 \mathrm{mg} \mathrm{P} \mathrm{kg}^{-1}$ under full sun (100 PS).

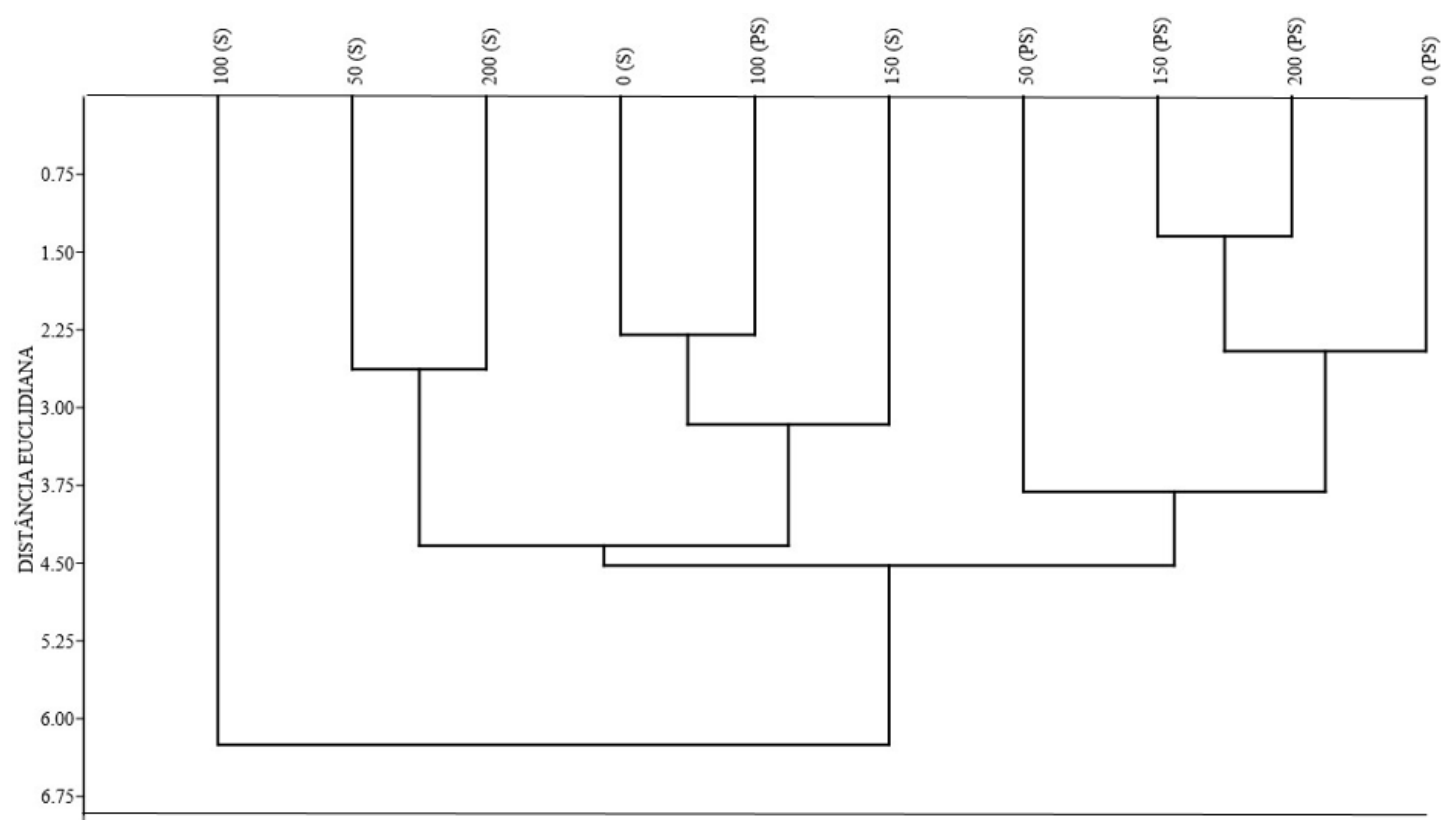

Figura 6. Euclidian distance of characteristics evaluated in $C$. xanthocarpa cultivated with phosphorus $(0,50,100$, 150 and $200 \mathrm{mg} \mathrm{kg} \mathrm{soil}{ }^{-1}$ ) under shading levels ( $\mathrm{S}=$ shading; $\mathrm{PS}=$ full sun $)$.

Figura 6. Distância Euclidiana de características avaliadas em C. xanthocarpa cultivadas com fósforo $(0,50,100$, 150 e $\left.200 \mathrm{mg} \mathrm{kg} \mathrm{solo}^{-1}\right)$ sob níveis de sombreamento ( $\mathrm{S}=$ sombreado; $\mathrm{PS}=$ pleno sol).

\section{DISCUSSION}

Possibly the higher plant height at both 150 and 240 DAT is associated with the fact that, generally, Campomanesia plants have slow growth (LORENZI, 2008). Similar results were described by Scalon et al. (2009). When evaluating the initial growth of Campomanesia adamantium $\mathrm{O}$. Berg., which belongs to the same family (Myrtaceae), they described that this slow growth is due to genetic factors of the plant. In addition, it should be noted that at 160 DAT the winter period began, which may have reduced the growth rate of the plants. A fact to be highlighted is that considering that the height values did not differ statistically between 150 and 240 DAT, the period of permanence of these plants in the initial growth conditions may be reduced, so they can be transplanted to the field.

The largest stem diameter of the collection with increasing phosphorus addition is attributable to the fact that this nutrient is part of the structure of the plant and several key molecules in its metabolism, composing membranes (phospholipids), RNA, DNA, ATP and carbohydrate esters (FREIBERGER et al., 2014). According to Martins et al. (2015), with the increase in shading, the photosynthetic rate reduces and, consequently, the amount of photoassimilates is reduced, providing a gradual increase in the diameter of the collar throughout the cultivation cycle. The smallest diameter under full sun at 240 DAT may be related to the lower water turgidity of the plant by the increase in temperature, which reached $33.7^{\circ} \mathrm{C}$ starting from 205 DAT, while in the shade the conditions were more favorable because of the use of Sombrite. Similarly, Felsemburgh et al. (2016) described that Aniba parviflora (Meisn) Mez. plants under shaded environment also presented larger diameter.

The greater number of leaves in shaded plants can be considered a mechanism of morphophysiological adaptation in order to increase the capture of light, maximizing the photosynthetic efficiency of the plant, since there is an increment per unit of photosynthesizing surface, ensuring greater use of light (GOBBI et al., 2011). Regarding the RHD value, this response can be considered as morphological plasticity of the species as a strategy to escape the conditions of low light intensity, since they grow rapidly in these environments (ALBUQUERQUE et al., 2015). A fact to be highlighted is the regrowth capacity of the species, since when in the period of extreme temperatures, the plants lost the leaves, presenting regrowth approximately after 15 days (Figure 1F). The

FLORESTA, Curitiba, PR, v. 50, n. 4, p. 1741 - 1750, out/dez 2020.

Silverio, J. M. et.al.

ISSN eletrônico 1982-4688 
temperature of the environment was the same for all plants, but shaded plants were less exposed to high temperatures because of the shading screen. Under full sun environment there is direct exposure of plants to high temperatures, causing water loss by leaf transpiration and defoliation as a response because there is greater evaporation of the water from the substrate, possibly causing a stress condition attributable to water deficit.

Plants under low light availability tend to invest more photoassimilates in the aerial part (FELSEMBURGH et al., 2016). However, this growth can be considered etiolation induced by low light intensity because it was favored by the lower temperatures in the leaves. In this light condition, plants may have less stomatal functioning, causing limitation of $\mathrm{CO}_{2}$ assimilation, promoting reduction of the photosynthetic activity, making it necessary the rustification of the plants in this initial phase. The reduction of RHD in shaded plants at 240 DAT is due to the increase in SD, being a desirable indicator, as it favors the translocation of photoassimilates, contributing to morphometric stability, ensuring the survival capacity of young plants.

The lower chlorophyll index in full sun leaves can be explained by the fact that under high light radiation intensities, chlorophyll molecules are sensitive to photo-oxidation, indicating that this condition causes damage to chloroplasts. On the other hand, in leaves grown under shades there is an increase of this pigment in response to the low incidence of luminosity (MOTA et al., 2012), that is, compensation of the energy balance.

The light conditions changed the value of $\mathrm{F}_{0}$. Under high light incidence, structural changes in photosynthetic pigments may occur as a result of the increase in supra-optimal temperatures due to higher incident radiation, characterizing drastic changes in $F_{0}$ values (CAMPOSTRINI, 2001). Dias and Marenco (2007) evaluating photosynthesis and photoinhibition in young plants of Swietenia macrophylla King and Minquartia guianensis Aubl. as a function of luminosity, observed that the exposure of plants to full sun caused variations in the initial fluorescence of chlorophyll-a, with an increase in values in high irradiance and moderate temperatures.

$\mathrm{F}_{\mathrm{m}}$ is an indicator that represents the maximum fluorescence intensity when practically all quinone is reduced and the reaction centers reach their photochemical reaction maximum capacity (SUASSUNA et al., 2011). The higher the value the better the energy will be used. The reduction of $F_{m}$ characterizes quinone A reduction deficiency, which may be associated with the inactivation of PS II in the membranes of the thylakoids, affecting electron mobility between the photosystems (CRUZ et al., 2006). Santos et al. (2011) describe that the increase in irradiance reduces the values of $F_{m}$. In these premises, the increase of $F_{0}$ and the decrease of $F_{m}$ represents damage to the PS II, that is, they represent luminous stress, compromising electron transfer activities, represented by $F_{v}$ $\left(\mathrm{F}_{\mathrm{m}}-\mathrm{F}_{0}\right)$, which, in turn, reduces photochemical efficiency.

In general, the highest photochemical indicators with $\mathrm{P}$ doses for $C$. xanthocarpa plants reinforce our hypothesis that phosphate fertilization acts in the mitigation of luminous stress, due to both high and low availability in the cultivation environments. P favors ATP production and electron transport (TAIZ et al., 2017), contributing to energy conversion and keeping PS II processes more stable.

The fact that the higher photochemical quantum efficiency of photosystem II $\left(\mathrm{F}_{\mathrm{v}} / \mathrm{F}_{\mathrm{m}}\right)$ occurred in a full sun environment in association with phosphate fertilization can be explained by the fact that the increased availability of incident photons significantly raised this photosynthetic indicator, and also that phosphorus contributes substantially to the photochemical process owing to the effective participation of this nutrient in the formation of ATP and NADPH (DOMINGUES et al., 2010), mitigating photoinhibitory damage.

Similar results were also observed by Cunha et al. (2016), when evaluating seedlings of Ochroma pyramidale (Cav. Ex Lamb.) Urb) submitted to phosphate fertilization in irradiance contrasting conditions, verified that the addition of $\mathrm{P}$ to the culture substrate promoted photochemical quantum yields similar to those of the shaded environment, indicating stability of activities in PS II, as observed in this study.

The parameters of fluorescence emission are important in understanding the integrity of photochemical processes and the ability to acclimatize plants to inhospitable conditions, since the higher values of the $F_{v} / F_{0}$ ratio demonstrate that $C$. xanthocarpa can optimize the use of light due to their greater conversion of absorbed energy, as well as lower dissipation, which contributes to adequate photochemical yield. Under full sun the plants of $C$. xanthocarpa reach their light saturation point in a shorter time, the leaves presented energy release mechanism in form of fluorescence, represented by the $\mathrm{F}_{0} / \mathrm{F}_{\mathrm{v}}$ ratio (maximum non-photochemical yield), contributing to the mitigation of damage to the photosynthetic apparatus. Furthermore, it is emphasized that because this method is not destructive, it is possible to identify the stress conditions for the plants, aiming to execute the rustification of plants at a young age, that is, verifying the appropriate moment of transplantation considering the luminous environment.

Regarding principal component analysis (PCA), this multivariate statistical model generates new variables that are linear functions of the original variables, thus the main objective of this type of analysis is to reduce the dimensionality of the data set, retaining information in a smaller number of components (SILVA; SBRISSIA, 2010), according to its constitutional contribution based on the burdens of factorial scores, that is, the higher the PC value, the higher its contribution. In this sense, the height and LN characteristics were eliminated

FLORESTA, Curitiba, PR, v. 50, n. 4, p. 1741 - 1750, out/dez 2020.

Silverio, J. M. et.al.

ISSN eletrônico 1982-4688 
due to the low representativeness. Considering the grouping based on the similarity dendogram of the evaluated characteristics, it was observed that plants under full sun in association with $100 \mathrm{mg} \mathrm{kg}^{-1}$ of $\mathrm{P}$ presented similar performance to the plants cultivated under shading without addition of $\mathrm{P}$, demonstrating that $C$. xanthocarpa plants submitted to high irradiances when supplemented with phosphorus can efficiently respond to stress by excess of luminosity.

The young plants of $C$. xanthocarpa in the initial phase possibly have potential for being inserted in areas with different light gradients, considering the adequate amount of fertilizer requiring, such as degraded areas, which may require higher doses of $\mathrm{P}$ in order to mitigate photoinhibitory damage of the photochemical process. Another alternative is to insert them in multi stratified agroforestry systems under the canopy of other tree species, characterizing underbrush conditions, with low doses of P. However, we emphasize that the initial growth responses, that is, in the seedling phase these responses are not sufficient to predict development and productivity information, requiring further agronomic and forestry studies.

From this study, it was found that $C$. xanthocarpa responded differently regarding shading levels and phosphate fertilization, demonstrating that studies associating mineral nutrition should be conducted, especially in the initial phase, considering that this silvicultural management contributed substantially to the stability of photochemical processes of photosynthesis. However, with the exception of the stem diameter, the other growth indicators were not influenced by phosphorus. In future perspectives, research should be carried out using other macronutrients to verify the expression maximum potential, especially considering that ex situ cultivation information of the species is still incipient.

\section{CONCLUSION}

- The young plants of Campomanesia xanthocarpa O. Berg cultivated under shading showed higher photochemical yield and initial growth with the addition of low phosphorus doses to the soil (10-35 mg $\mathrm{P} \mathrm{kg}$ soil $\left.^{-1}\right)$. For cultivation under full sun, the addition of $100 \mathrm{mg} \mathrm{P} \mathrm{kg} \mathrm{soil}^{-1}$ favored stable photochemical indicators.

\section{ACKNOWLEDGEMENTS}

The authors thank the Foundation for the Development of Education, Science, and Technology of the State of Mato Grosso do Sul (FUNDECT) and the Coordination for the Improvement of Higher Education Personnel (CAPES) for the financial support associated with the development and dissemination of this work, and the National Council for Scientific and Technological Development (CNPq) for the research scholarship.

\section{REFERENCES}

ALBUQUERQUE, T. C. S.; EVANGELISTA, T.C.; NETO, A. A. R. A. Níveis de sombreamento no crescimento de mudas de castanheira do Brasil. Revista Agroambiente, Boa vista, v. 9, n. 4, p. 440-445, 2015.

CAMARGO, S. M.; BARBOSA, D. S.; RESENDE, H. R.; KORNDORFER, H. G.; PEREIRA, H. S. Fósforo em solos de Cerrado submetidos à calagem. Bioscience Journal, Uberlândia, v. 26, n. 2, p. 187-194, 2010.

CAMPOSTRINI, E. Fluorescência da clorofila $\boldsymbol{a}$ : considerações teóricas e aplicações práticas. Rio de Janeiro: UFNF, 2001.

CÂNDIDO, J. B.; LIMA, D. P.; TEIXEIRA, P. R.; SOUZA, P. B. Florística do estrato arbustivo-arbóreo de uma área de Cerrado sensu stricto, Gurupi, Tocantins. Enciclopédia Biosfera, Goiânia, v. 13, n. 24, p. 17-45, 2016.

COELHO, A.M. Agricultura de precisão: manejo da variabilidade espacial e temporal dos solos e das culturas. Tópicos em Ciência do Solo. Viçosa: Sociedade Brasileira de Ciência do Solo, 2003. v. 3, p.259-290.

CRUZ, M. C. M.; SIQUEIRA, D. L.; SALOMÃO, L. C. C.; CECON, P. R. Fluorescência da clorofila $a$ em folhas de tangerineira 'ponkan' e limeira ácida 'tahiti' submetidas ao estresse hídrico. Revista Brasileira de Fruticultura, Jaboticabal, v. 31, n. 3, p. 896-901, 2009.

CUNHA, H. F. V.; GONSALVES, J. F. C.; JUNIOR, U. M. S.; FERREIRA, M. J.; PEIXOTO, P. H. P. Biomassa, trocas gasosas e aspectos nutricionais de plantas jovens de pau de balsa (Ochroma pyramidale (Cav. Ex Lamb.) Urb.) submetidas à fertilização fosfatada em ambientes contrastantes de irradiância. Scientia Forestalis, Piracicaba, v. 44, n. 109, p. 215-230, 2016.

FLORESTA, Curitiba, PR, v. 50, n. 4, p. 1741 - 1750, out/dez 2020.

Silverio, J. M. et.al.

ISSN eletrônico 1982-4688 
DALANHOL, S. J.; NOGUEIRA, A. C.; GAIAD, S.; KRATZ, D. Efeito de Micorrizas e da fertilização no crescimento de mudas de Campomanesia xanthocarpa (Mart.) O. Berg., produzidas em diferentes substratos. Ciência Florestal, Santa Maria, v. 27, n. 3, p. 931-945, 2017.

DIAS, D. P.; MARENCO, R. A. Fotossíntese e fotoinibição em mogno e acariquara em função da luminosidade e temperatura foliar. Pesquisa Agropecuária Brasileira, Brasilia, v. 42, n. 3, p. 305-311, 2007.

DOMINGUES, T. F.; MEIR, P.; FELDPAUSCH, T. R.; SAIZ, G.; VEENENDAAL, E. M.; SCHRODT, F.; BEID, M.; DJAGBleteY, G.; HIEN, F.; CAMPAORE, H.; DIALLO, A.; GRACE, J.; LLOYD, J. Co-limitation of photosynthetic capacity by nitrogen and phosphorus in West capacity by nitrogen and phosphorus in West Africa Woodlands. Plant, Cell and Environment, Hudson, v. 33, n. 6, p. 959-980, 2010.

FELSEMBURGH, C. A.; SANTOS, K. J. S.; CAMARGO, P. B.; CARMO, J. B.; TRIBUZY, E. S. Respostas ecofisiológicas de Aniba parviflora ao sombreamento artificial. Pesquisa Florestal Brasileira, Colombo, v. 36, n. 87, p. 201-210, 2016.

FREIBERGER, M. B.; GUERRINI, I. A.; CASTOLDI, G.; PIVETTA, G. Adubação fosfatada no crescimento inicial e na nutrição de mudas de pinhão- manso. Revista Brasileira de Ciência do Solo, Viçosa, v. 38, n.1, p. 232-239, 2014.

GOBBI, K. F.; GARCIA, R.; VENTRELLA, M. C.; NETO, A. F. G.; ROCHA, G.C. Área foliar específica e anatomia foliar quantitativa do capim-braquiária e do amendoim-forrageiro submetidos a sombreamento. Revista Brasileira de Zootecnia, Piracicaba, v. 40, n. 7, p. 1436-1444, 2011.

KLAFKE, J. Z.; SILVA, M. A.; PANINGAS, T. F.; BELLI, K. C.; OLIVEIRA, M. F.; BARICHELLO, M. M.; RIGO, F. K.; ROSSATO, M. F.; SANTOS, A. R. S.; PIZZOLATTI, M. G.; FERREIRA, J.; VIECILI, P. R. N. Effects of Campomanesia xanthocarpa on biochemical, hematological and oxidative stress parameters in hypercholesterolemic patients. Journal of Ethnopharmacology, n. 127, p. 299-305, 2010.

LORENZI, H. Árvores brasileiras: manual de identificação e cultivo de plantas arbóreas nativas do Brasil.5. ed. Nova Odessa: Instituto Plantarum, 2008. v. 1. 384 p.

MARTINS, M. Q.; MARÇAL, T. S.; SOUZA, M. F.; COELHO, R. I. Influência do sombreamento no crescimento de mudas de laranjeura 'Folha Murcha'. Revista de Ciências Agrárias, Lisboa, v. 38, n.3, p. 407-413, 2015.

MOTA, L. H. S.; SCALON, S. P. Q.; HEIZ, R. Sombreamento na emergência de plântulas e no crescimento inicial de Dipteryx alata Vog. Ciência Florestal, Santa Maria, v. 22, n. 3, p. 423-431, 2012.

SANTOS, D.; SIQUEIRA, D. L.; CECON, P. R. Indução floral de limeiras ácidas 'Tahiti' submetidas a baixas temperaturas. Ciência Rural, Santa Maria, v. 41, n. 3, p. 397-403, 2011.

SANTOS, J. Z. L.; RESENDE, A. V.; NETO, A. E. F.; CORTE, E. F. Crescimento, acúmulo de fósforo e frações fosfatadas em mudas de sete espécies arbóreas nativas. Revista Árvore, Viçosa, v. 32, n. 5, p. 799-807, 2008.

SCALON, S. P. Q.; LIMA, A. A.; FILHO, H. S.; VIEIRA, M. C. Germinação de sementes e crescimento inicial de mudas de Campomanesia adamantium Camb.: efeito da lavagem, temperatura e de bioestimulantes. Revista Brasileira de Sementes, Londrina v.31, n.2, p. 096-103, 2009.

SILVA, S. C.; SBRISSIA, A. F. Análise de componentes principais entre características morfogênicas e estruturais em capim-marandu sob lotação contínua. Ciência Rural, Santa Maria, v. 40, n. 3, p. 690-693, 2010.

SOBRAL, M.; PROENÇA, C.; SOUZA, M.; MAZINE, F.; LUCAS, E. 2015 Myrtaceae in Lista de Espécies da Flora do Brasil. Jardim Botânico do Rio de Janeiro. Disponível em: < http://floradobrasil.jbrj.gov.br/jabot/floradobrasil/FB171>. Acesso em: 18 Dez. 2018.

SUASSUNA, J. F.; MELO, A. S.; COSTA, F. S.; FERNANDES, P. D.; FERREIRA, R. S.; SOUZA, M. S. S. Eficiência fotoquímica e produtividade de frutos de meloeiro cultivado sob diferentes lâminas de irrigação. Semina: Ciências Agrárias, Londrina, v. 32, n. 4, p. 1251-1262, 2011.

TAIZ, L.; ZEIGER, E.; MOLLER, I.; MURPHY, A. Fisiologia e Desenvolvimento Vegetal. 6. ed. Porto Alegre: Artmed, 2017. 888 p.

ZUNINGA, A.; COQUEIRO, K. T. O.; SIQUEIRA, A. S. Capacidade antioxidante de frutos nativos do cerrado (Hancornia speciosa, Campomanesia xanthocarpa, Eugenia dysenterica) uma breve revisão. Revista Desafios, Tocantins, v. 5, n. 1, p.128-134, 2018.

FLORESTA, Curitiba, PR, v. 50, n. 4, p. 1741 - 1750, out/dez 2020.

Silverio, J. M. et.al.

ISSN eletrônico 1982-4688 